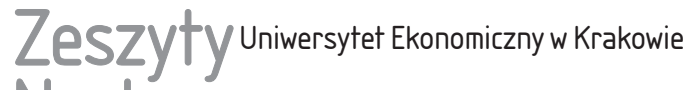 Naukowe
}

$7(955)$

ISSN 1898-6447

Zesz. Nauk. UEK, 2016; 7 (955): 41-56

DOI: 10.15678/ZNUEK.2016.0955.0703

Dagmara Lewicka

Katarzyna Krot

Dawid Ksiązek

\section{Metodyczne aspekty badania zaufania w naukach o zarządzaniu}

\section{Streszczenie}

Artykuł prezentuje zagadnienia związane z badaniem zaufania w naukach o zarządzaniu. Zaufanie rozpatruje się w różnych kontekstach i przekrojach. Wskazuje się ponadto na zróżnicowane źródła i wymiary zaufania, a także kulturowe zakorzenienie tego konstruktu i wiele innych jego cech, które utrudniają analizy i uzgodnienia w zakresie badań różnych autorów. Trudności w badaniu zaufania wynikają także z jego natury jako konstruktu poznawczego, którego analizy dokonuje się często na podstawie subiektywnego postrzegania respondentów. Celem artykułu jest kompleksowe ujęcie problematyki zaufania z uwzględnieniem trudności związanych z jego mierzeniem.

Słowa kluczowe: zaufanie organizacyjne, zaufanie międzyorganizacyjne, osobowa skłonność do zaufania, metodyka badań.

Klasyfikacja JEL: C1.

Dagmara Lewicka, AGH Akademia Górniczo-Hutnicza, Katedra Zarządzania Przedsiębiorstwem, 30-067 Kraków, ul. A. Gramatyka 10, e-mail: dagal@poczta.fm

Katarzyna Krot, Politechnika Białostocka, Katedra Marketingu i Przedsiębiorczości, 16-001 Kleosin, ul. o. S. Tarasiuka 2, e-mail: katarzynakrot@gmail.com

Dawid Książek, AGH Akademia Górniczo-Hutnicza, Katedra Zarządzania Przedsiębiorstwem, 30-067 Kraków, ul. A. Gramatyka 10, e-mail: dawidksiazek9@gmail.com 


\section{Wprowadzenie}

Problematyka zaufania jest przedmiotem badań autorów reprezentujących różne dyscypliny naukowe, takie jak: ekonomia, zarządzanie, socjologia, nauki polityczne, psychologia. Zaufaniem można zajmować się w skali makro (np. zaufanie systemowe), mezo (zaufanie organizacyjne) oraz mikro, w wymiarze jednostkowym [Bigley i Pearce 1998]. Na poziomie makroekonomicznym zaufanie badane jest w kontekście wzrostu gospodarczego [Beugelsdijk, Groot i Schaik 2004], nierówności dochodowych [Gori-Maia 2013], stabilności demokratycznej [Inglehart 1999] czy poziomu przestępczości [Rosenfeld, Messner i Baumer 2001].

W naukach o zarządzaniu zaufanie rozpatrywane jest w czterech głównych nurtach jako:

- interpersonalne zaufanie wewnątrzorganizacyjne pomiędzy przełożonymi i podwładnymi oraz pomiędzy współpracownikami,

- impersonalne, instytucjonalne zaufanie wewnątrzorganizacyjne pracowników do organizacji,

- zaufanie w relacjach międzyorganizacyjnych (interorganizacyjne),

- w obszarze marketingu zaufanie klientów do organizacji, także do zakupów on line.

Stosunkowo nowym wątkiem w badaniach dotyczących zaufania są badania nad zaufaniem do nowych technologii [Lippert i Swiercz 2005]. Zaufanie w skali mikro analizowane jest na poziomie indywidualnym, międzyludzkim w rodzinie i w relacjach intymnych i koleżeńskich [Larzelere i Huston 1980], np. w badaniu diad koncentrowano się na odwzajemnianiu zaufania, wpływie zaufania jednej ze stron na powstawanie zaufania partnera, jego symetryczności i asymetryczności oraz ich konsekwencjach [Korsgaard, Brower i Lester 2015].

Zaufanie jest więc zróżnicowanym i wielowymiarowym konstruktem, ponadto dynamicznym i zmieniającym się w czasie. Wynika $\mathrm{z}$ historii wzajemnych kontaktów. Wydaje się zasobem, który rośnie wraz z intensywnością jego użytkowania i słabnie, jeśli się go nie wykorzystuje [Atkinson i Butcher 2003]. Istotną cechą zaufania jest też jego stopniowalność, która zakłada możliwość rozwoju zaufania w czasie, ale też powrotu na niższy etap rozwoju zaufania we wzajemnych relacjach [Atkinson i Butcher 2003].

Wielość definicji zaufania i modeli pomiarowych utrudnia porównania w zakresie wyników prac różnych autorów. Taki stan rzeczy wskazuje również na ograniczenia dotyczące dostępnych narzędzi służących mierzeniu zaufania. Trudności w badaniu zaufania pojawiają się także dlatego, że mamy do czynienia ze zjawiskiem, które jest nienamacalne, a jedynie odczuwane czy postrzegane [DeVellis 1991]. Autorzy wskazują także, że pomimo dużej liczby publikacji na 
temat zaufania w naukach o zarządzaniu wciąż podchodzi się do tego zagadnienia fragmentarycznie [McEvily, Perrone i Zaheer 2003].

Celem niniejszego opracowania jest wskazanie wyzwań koncepcyjnych i metodycznych związanych z badaniem zaufania. Niniejszy artykuł skupia się w szczególności na dwóch z nich: związanych z definiowaniem zaufania oraz wynikających z natury zaufania jako konstruktu postrzeganego (perceived). Ponadto skupiono się na aspektach związanych z pomiarem zaufania.

\section{Trudności $w$ badaniu zaufania wynikające $\mathrm{z}$ różnic $w$ jego definiowaniu}

Jedną z trudności w prowadzeniu badań nad zaufaniem są różnice w definiowaniu tego konstruktu w naukach o zarządzaniu. Autorzy wskazują wręcz na proliferację definicji zaufania, która zdaniem A. Sankowskiej [2011] i tak nie wyczerpuje wszystkich możliwości jego rozumienia. L.T. Hosmer [1995] wskazuje na istnienie co najmniej pięciu kontekstów, w których definiowane jest zaufanie. Są to:

- indywidualne oczekiwania - związane są z wrażliwością partnera i stopniem jego optymizmu w relacjach $z$ innymi; stopniem, w jakim jest w stanie zawierzyć, zrezygnować z kontroli na rzecz zaufania, odnośnie do przekonań o stałości porządku społecznego, kompetencji czy standardów moralnych osób, którym zawierza;

- relacje interpersonalne - oparte na współpracy i odwzajemnianiu, związane z relacjami z osobą ,godną zaufania”, która będzie działać na rzecz osoby obdarzającej zaufaniem bez względu na postrzegany krótkoterminowo interes własny, ze względu na posiadane cechy, takie jak uczciwość, spójność, lojalność i otwartość, kompetencje, i łączące je relacje;

- wymiana ekonomiczna - podejście oparte na założeniu, że w relacjach biznesowych nie należy wierzyć ani jednostkom, ani partnerom biznesowym, ponieważ ich działania mogą być oportunistyczne i służyć realizacji własnych interesów. O. Wiliamson [1985] wykazał w swych badaniach, że mimo iż części partnerów biznesowych można ufać, trudno określić, którym z nich. W związku z tym podmioty muszą ponosić koszty związane z zabezpieczeniem transakcji, których mogłyby uniknąć w sytuacji wzajemnego zaufania;

- struktury społeczne - zaufanie ma w znacznym stopniu charakter społeczny, nie tylko indywidualny. W związku z tym, że interakcje mają charakter kompleksowy (ufamy komuś, kto z kolei ufa innym osobom), tworzą się sieci zaufania, w których zaufanie wzmacniane jest historią wzajemnych kontaktów i stopniowym tworzeniem się wspólnych dla grupy norm; 
- zasady etyczne - zaufanie związane jest z przekonaniem osób, grup lub podmiotów o tym, co jest etycznie uzasadnione i moralnie poprawne, przy czym L.T. Hosmer [1995] podkreśla, że etycznie uzasadnione zachowanie przedkłada interesy społeczeństwa nad interesy indywidualne. Zaufanie do podmiotu związane jest $\mathrm{z}$ prowadzeniem biznesu w sposób etyczny z poszanowaniem praw interesariuszy. Pojęcie zaufania łączone jest często z pojęciem klimatu etycznego. Dwa podstawowe wymiary klimatu etycznego - życzliwość i zasady, związane są z istotą zaufania i odgrywają znaczącą rolę w jego powstawaniu i utrwalaniu. Klimat etyczny wpływa na decyzje i zachowania pracowników, wskazując, co w organizacji jest cenione i pożądane, a co nie jest akceptowane [Martin i Cullen 2006].

Ponadto zaufanie ma rozbudowaną strukturę, którą można badać m.in. w następujących aspektach:

- w kontekście perspektyw badania: zaufanie wewnątrzorganizacyjne - horyzontalne, instytucjonalne, normatywne [Meyer, Davis i Schooman 1995] oraz zaufanie interorganizacyjne - między organizacją a interesariuszami, między organizacjami, między organizacjami a klientami [Sankowska 2011];

- wymiarów zaufania, np. kompetencje, uczciwość, konsekwencja, dyskrecja, rzetelność, spełnianie obietnic, lojalność, dostępność, otwartość, wrażliwość i ogólna wiarygodność, życzliwość, przewidywalność, kwalifikacje, skuteczność, opiekuńczość, pryncypialność, uczciwość i inne [McCole 2002];

- zakorzenienia w kulturze organizacyjnej; zaufanie jest traktowane przez badaczy jako wymiar klimatu organizacyjnego; zaufanie wewnątrzorganizacyjne jest często utożsamiane $\mathrm{z}$ klimatem zaufania $\mathrm{w}$ organizacji, a doświadczany przez pracowników klimat zaufania odzwierciedla percepcję środowiska pracy i wyznacza ramy dla zachowań i decyzji pracowników [Altuntas i Baykal 2010];

- wzajemnej komunikacji jako warunku jego występowania, ale też podstawy rozwoju otwartej komunikacji i dialogu [Svensson 2006]; efektywna komunikacja i wymiana informacji są dodatnio skorelowane z poziomem zaufania w relacjach biznesowych [Fischer 2013], zaufanie jest warunkiem efektywnej komunikacji w organizacjach i zespołach [Blomqvist 2002]. Z drugiej strony zaufanie jest także efektem komunikacji i interakcji [Gibson i Manuel 2003]. Prowadzi to do wniosku, że zaufanie jest zarówno warunkiem satysfakcjonujących interakcji, jak i ich rezultatem;

- podstaw czy źródeł zaufania. Mogą być one: poznawcze, (racjonalne, zadaniowe oparte na kompetencjach, kalkulacyjne, funkcjonalne, związane z rolą), oparte na racjonalnej ocenie i przekonaniu, że osoba pełniąca daną funkcję będzie zachowywać się kompetentnie, odpowiedzialnie i zgodnie ze swoją rolą [Morita i Burns 2012], oraz afektywne (interpersonalne, oparte na relacjach), oparte na pozytywnych emocjach, otwartej komunikacji, uczciwości, doświad- 
czaniu pozytywnych interakcji, dobrych intencji i dbałości o podtrzymywanie relacji [Lencioni 2012];

- dynamiczności i zmienności w czasie. Wielu autorów wskazuje, że zaufanie rozwija się w czasie, począwszy od jego najbardziej prostych form, opartych na kalkulacji czy strachu, aż do form najbardziej zaawansowanych takich jak zaufanie oparte na identyfikacji i wiedzy [Hosmer 1995, Sako 2006];

- w świetle wzajemnych relacji - udzielający zaufania i obdarzony zaufaniem [Baccarani 1995];

- względem adresatów, treści oraz podmiotów zaufania: interpersonalne, społeczne, publiczne, technologiczne, konsumpcyjne, on line systemowe i uogólnione [Zieliński 2012].

Powyższa różnorodność sposobów definiowania oraz złożoność struktury zaufania warunkuje konieczność zawężenia prowadzonej analizy do wyboru jednego lub kilku aspektów. W związku z tym osoba projektująca badania musi zmierzyć się z właściwym określeniem celu badawczego, w taki sposób by odzwierciedlał on wszystkie możliwe aspekty zaufania w badanym fragmencie rzeczywistości organizacyjnej.

Rozróżnienie wiedzy na potoczną oraz naukową wydaje się być istotne w kontekście prowadzenia badań nad zaufaniem. Trudność w prowadzeniu badań przejawia się w tym przypadku w możliwości odmiennego rozumienia przedmiotu obserwacji przez naukowca oraz osoby tworzące badaną próbę. Nie ma bowiem gwarancji, że badani będą mieć wiedzę naukową na temat badanego konstruktu. Na kwestię tę zwracają również uwagę N.A.D. Connel i R. Mannion [2006], wskazując, że potoczne rozumienie zaufania może się sprowadzać jedynie do odczucia wiary w czyjeś dobre intencje i zapewnienia, które gwarantują poczucie bezpieczeństwa i wewnętrznego spokoju [Sokołowska 2015]. Należy zatem uwzględnić fakt, że badane jednostki nie muszą rozumieć zaufania w ten sam sposób co badacz, który rzetelnie przygotował skalę badawczą na podstawie dostępnej literatury naukowej.

\section{Trudności w badaniu zaufania wynikające $z$ natury zaufania jako konstruktu postrzeganego}

Powyższe trudności w badaniu zaufania wynikają z natury konstruktu, która sprawia, że należy go zakwalifikować jako konstrukt psychospołeczny. Bez względu na to, czy zaufanie traktuje się jako funkcję przyszłych i teraźniejszych zachowań [Good 1988], czy jako relatywnie stałą cechę danej osoby [Wrightsman 1966], metodyka badań odnosi się do opinii respondentów na temat zaufania, co ma związek z postrzeganiem otaczającego ich środowiska. Jest to spowodowane 
tym, że zaufanie podobnie jak inne psychospołeczne komponenty występujące w zarządzaniu organizacją (np. satysfakcja, zaangażowanie w relacje z marką, relacje w łańcuchu dostaw, klimat sprawiedliwości, odczuwane wsparcie organizacji, wsparcie przełożonego) stanowi tzw. komponent postrzegany. Postrzeganie jest więc jednym z wyznaczników konstruktów psychospołecznych w organizacji rozumianych jako stany wywołane przez stosunek jednostki do środowiska. Wzrost popularności badań nad zmiennymi związanymi z postrzeganiem datowany jest na okres po 2000 r. [Gojny-Zbierowska 2015]. Wydaje się, że tendencja ta związana jest z coraz większą koncentracją badaczy na odczuciach (percepcji) pracownika, klienta czy interesariuszy, ponieważ odczucia te wpływają na ich decyzje i zachowania.

\section{Kognitywność zaufania}

Należy także podkreślić trudność w badaniu zaufania, która związana jest z czynnikami mogącymi przyczynić się do odmiennego rozumienia tego samego aspektu zaufania przez osoby badane. Czynniki te mogą bowiem wpływać na postrzeganie jednostek. Powyższa trudność w prowadzeniu badań nad zaufaniem wiąże się ze zjawiskiem, które określa się jako kognitywność. Treść kognitywna dotyczy procesów i struktur poznawczych człowieka, w związku z tym odnosi się do percepcji jako mechanizmu tworzenia doświadczenia i wiedzy o otoczeniu [Piórkowska 2014]. Zaufanie jest kategorią kognitywną, ponieważ jest rodzajem poznania. O zaufaniu do partnera decyduje wiedza o kwalifikacjach moralnych partnera lub jego skłonnościach osobowościowych. Ponadto w odniesieniu do zaufania należy zwrócić uwagę na pojęcie kategoryzacji, nierozłącznej w procesie percepcji i poznawania świata. Proces kategoryzacji polega na przyporządkowaniu kategoriom wynikającym z uprzedniego doświadczenia zdobywanych na bieżąco bodźców na podstawie zbudowanych wcześniej schematów pamięciowych [Pluwak 2009]. Proces ten warunkuje zapamiętywanie, zrozumienie, ocenę, a także postawy i przyszłe zachowania człowieka [Cwalina i Falkowski 2005].

Trudności w badaniu zaufania pojawiają się także w związku z emocjonalnością człowieka. Emocje stanowią bowiem o specyficznych oraz mocno zindywidualizowanych reakcjach behawioralnych w odpowiedzi na sytuację ważną dla danej osoby [Gerrig i Zimbardo 2006]. W kontekście prowadzonej analizy należy zwrócić uwagę na jeden z czterech wymienianych systemów uruchamiania emocji, a mianowicie na system poznawczy [Miszczak 2010]. Według tego systemu pojawienie się emocji może być wywołane oceną sytuacji w zależności od potrzeb jednostki, celów i wartości. Emocje mogą pojawiać się w wyniku percepcji, przywołanych z pamięci informacji oraz sposobu ich przetworzenia 
w trakcie procesów myślowych [Migdał 2003]. W związku z tym można wyobrazić sobie ogromną różnorodność rozumienia zaufania przez osoby badane jako konstruktu determinowanego emocjami człowieka. Powyższe rozważania wskazują na znaczny subiektywizm w zakresie rozumienia pojęcia zaufania, co może mieć także wpływ na uzyskiwane przez badaczy wyniki. Jak wskazuje J. Wierzbiński [2009], nawet w przypadku precyzyjnej operacjonalizacji pojęcia zaufania nadal można mieć wątpliwości, czy dwie osoby deklarujące zaufanie odczuwają dokładnie to samo. Ponieważ ta sama ocena w skali ocen może oznaczać dla poszczególnych jednostek coś zupełnie innego, dopiero dane pochodzące z odpowiednio dużej próby neutralizują błędy wynikające z odmiennego kalibrowania skal zaufania przez respondentów. Zdaniem J. Wierzbińskiego ze względu na to, że zaufanie jest kategorią subiektywną, nigdy nie powstanie niezawodne narzędzie pozwalające na porównywanie doznań różnych osób.

\section{Skłonność do zaufania}

Trudności w badaniu zaufania mogą wynikać również z różnic dotyczących osobowej skłonności do zaufania (trust propensity). Skłonność do zaufania to mocno zindywidualizowany komponent, który warunkuje gotowość do obdarzania zaufaniem lub do wyrażania nieufności względem innych [Van Dyne 2000]. Skłonność do zaufania jest traktowana jako wymiar osobowości. Wywiera pozytywny wpływ na indywidualny poziom zaufania jednostek. Niekoniecznie sugeruje, że dana osoba uważa wszystkich bez wyjątku za godnych zaufania, ale sprawia, że ogólnie osoba wykazuje tendencję do ufania innym w różnych sytuacjach [McKnight i Chervany 2001]. Osobowa skłonność do zaufania uzależniona jest od wielu czynników, takich jak: doświadczenie życiowe, typ osobowości, pochodzenie, wykształcenie i czynniki społeczno-ekonomiczne [Mayer, Davis i Schoorman 1995]. Skłonność do zaufania odgrywa dużą rolę w sytuacjach nowych i niejednoznacznych w przypadku ograniczonej dostępności do informacji o partnerze [Bigley i Pearce 1998].

Badania wskazują, że osoby posiadające wysoką skłonność do zaufania rzadziej oszukują lub kłamią, są mniej konfliktowe oraz wykazują większe poszanowanie dla racji innych. Skłonność do zaufania wpływa na wiele efektów istotnych dla organizacji, zarówno na poziomie indywidualnym, jak i organizacyjnym, takich jak: zachowania obywatelskie, chęć zmiany pracy, zaangażowanie w realizację celów i zadań, wydajność pracy [Colquitt i in. 2007]. Zaufanie traktowane jest $\mathrm{w}$ badaniach różnych autorów jako zarówno zmienna sytuacyjna, jak i interpersonalna. Różnice pomiędzy poziomem zaufania respondentów w poszczególnych wymiarach mogą być spowodowane właśnie różnicami indy- 
widualnymi w zakresie osobowościowej skłonności do zaufania. Przykładowo wysoka skłonność do zaufania będzie skutkować wyższym zaufaniem do instytucji czy ról społecznych. Dlatego istotne jest, aby w badaniach zaufania stosować także zmienną kontrolną ,skłonność do zaufania”.

\section{Zależność przyczynowo-skutkowa pomiędzy różnymi rodzajami zaufania}

Jak już wspomniano, osobowa skłonność do zaufania może wpływać na rezultat pomiaru zaufania w różnych przekrojach. Co więcej, większość badań potwierdza wysoką korelację miedzy zmiennymi charakteryzującymi różne rodzaje zaufania. Skupienie uwagi tylko na jednym rodzaju zaufania nie daje zatem pełnego obrazu, a niekiedy może prowadzić do fałszywych wniosków. Korelacje pomiędzy poszczególnymi rodzajami zaufania sprawiają, że konieczne jest całościowe podejście do zaufania organizacyjnego [Krot 2013].

P. Sztompka [2007] podkreśla, że możemy mówić o stopniowo rozszerzających się koncentrycznych kręgach zaufania: od najbardziej konkretnych relacji międzyosobowych do bardziej abstrakcyjnego odniesienia wobec struktur i instytucji społecznych lub odwrotnie.

Może się zdarzyć, że brak zaufania do menedżera jest nie tyle efektem jego niskich kompetencji menedżerskich, co przede wszystkim nieudolnego zarządzania organizacją i w konsekwencji rozciągnięcia tych negatywnych opinii również na bezpośredniego przełożonego. $Z$ kolei działania powodujące wysoki poziom zaufania instytucjonalnego, takie jak dbałość o klarowność procedur, poczucie sprawiedliwości czy budowanie wsparcia organizacji, może spowodować wzrost zaufania do menedżerów.

Podobnie zaufanie międzyorganizacyjne budowane jest w pewnym stopniu także przez relacje interpersonalne pomiędzy zwykle dwiema osobami reprezentującymi przedsiębiorstwa (np. kupującego i sprzedającego, kupującego i detalistę itp.). Zaufanie interpersonalne odgrywa więc kluczową rolę w rozwoju zaufania międzyorganizacyjnego [Mouzas, Henneberg i Naude 2007]. Choć te dwa rodzaje zaufania są ze sobą powiązane, to trzeba pamiętać, że są to zupełnie inne konstrukty [Weck i Ivanova 2013].

Budowanie zaufania rozpoczyna się od zaufania wstępnego, które zazwyczaj jest słabe i wynika $\mathrm{z}$ określonych przesłanek, np. aspektów instytucjonalnych. Końcowym efektem tego procesu powinno być dojrzałe zaufanie oparte na zdepersonalizowanych lub spersonalizowanych podstawach. W literaturze przedmiotu opisywane jest zjawisko transferu zaufania. Jest to sytuacja, w której tzw. wstępne czy początkowe zaufanie do jednej ze stron, do określonego podmiotu (osoby, 
grupy, organizacji), wynika z zaufania do strony trzeciej, czyli innego podmiotu, powiązanego z sytuacją dotyczącą relacji. Istnieje wiele źródeł, z których zaufanie może zostać przeniesione na inny podmiot [Stewart 2003]. Ogólnie przyjmuje się, że transfer może mieć charakter wewnątrzorganizacyjny lub międzyorganizacyjny. W przypadku zaufania organizacyjnego szczególnie istotne $\mathrm{w}$ procesie powstawania zaufania są: strategia, struktura organizacyjna, kultura organizacyjna, normy, wartości, procedury, w oparciu o które dokonuje się transfer zaufania na osoby powiązane z organizacją. Rzeczywisty lub potencjalny partner będzie bardziej skłonny ufać reprezentantowi organizacji charakteryzującej się stabilnymi i przewidywalnymi procedurami niż takiej, w której są one nieuporządkowane. W związku z tym w badaniach tego typu wielopłaszczyznowych relacji trudno uzyskać pomiar każdego z rodzajów zaufania.

\section{Wybrane metody badania zaufania}

Zaufanie cieszy się niesłabnącym zainteresowaniem badaczy reprezentujących różne dyscypliny naukowe od ponad 30 lat. Jeśli chodzi o rodzaje zaufania wewnątrzorganizacyjnego, uwaga badaczy skupiała się przede wszystkim na badaniu zaufania wertykalnego w relacjach przełożony podwładny [Ertürk 2010, Nienaber $i$ in. 2015]. Ostatnio większym zainteresowaniem cieszy się zaufanie impersonalne w relacjach pracownik-instytucja [Atkinson i Butcher 2003, Vanhala, Puumalainen i Blomqvist 2011]. Z kolei w związku z rosnącym znaczeniem efektywności zespołów (także zespołów wirtualnych) w osiąganiu sukcesu, konkurencyjności i innowacyjności organizacji coraz większą uwagę poświęca się zaufaniu horyzontalnemu [Glińska-Neweś i Haffer 2013, Glińska-Neweś 2013, Morita i Burns 2014]. Badania nad relacjami międzyorganizacyjnymi prowadzone w ostatnich latach jednoznacznie wskazują, że koniecznym elementem relacji biznesowych jest zaufanie, co sprawia, że znaczna grupa badaczy koncentruje się na problematyce tworzenia, podtrzymywania i rozwoju relacji międzyorganizacyjnych opartych na zaufaniu [Zang i Cohen 2008, Koopetycja... 2014]. Ostatnio zainteresowania badaczy koncentrują się także na aspektach procesu zaufania [Ekici 2013], a także komponentów zaufania, w tym elementów poznawczych i afektywnych [Schoorman, Mayer i Davis 2007].

Wielowymiarowość oraz mnogość sposobów definiowania zaufania powoduje, że nie istnieje jedno narzędzie badawcze lub jedna metodyka, która w sposób całościowy umożliwiłaby badanie tego konstruktu [Paine 2003].

W badaniach zaufania najczęściej wykorzystywane jest jedno z podejść. Pomiar zaufania odbywa się na podstawie osobistej oceny respondenta dokonanej za pomocą wywiadu lub badania ankietowego. W podejściu tym istnieje zezwolenie na pewne modyfikacje metod pomiaru [Seppanen, Blomqvist i Sundqvist 
2007]. Zdaniem A. Sankowskiej [2011] zaufanie jako kategoria nieobserwowalna nie może podlegać pomiarowi bezpośrednio, ale za pośrednictwem innych zmiennych, które odnoszą się do obserwowalnych cech. W związku z tym instrumentem pomiarowym jest skala, czyli zbiór pozycji (twierdzeń) odzwierciedlających właśnie te obserwowalne cechy zaufania. Autorzy badający zaufanie, nawet jeśli opierają się na którejś z istniejących skal, zwykle modyfikują ją przez przystosowanie do potrzeb prowadzonych badań. Tabela 1 zawiera przykładowe skale pomiarowe zaufania stosowane przez różnych autorów.

Tabela 1. Skale pomiarowe zaufania

\begin{tabular}{|l|l|c|}
\hline \multicolumn{1}{|c|}{ Autorzy } & \multicolumn{1}{c|}{ Obszar badań } & Liczba twierdzeń \\
\hline $\begin{array}{l}\text { L.L. Cumming i P. Bromiley } \\
\text { (1996) }\end{array}$ & Zaufanie ogólnie & 12 \\
\hline A. Zaheer i in. (1998) & Zaufanie pomiędzy firmą a dostawcami & 10 \\
\hline R.C. Mayer i. in. (1995) & Zaufanie do najwyższego kierownictwa & 18 \\
\hline S. Tzafrir i L. Dolan (2004) & Zaufanie pomiędzy pracownikami & 14 \\
\hline $\begin{array}{l}\text { A. Hadjikhani i P. Thelenius } \\
\text { (2005) }\end{array}$ & Zaufanie klienta & 13 \\
\hline M. Vanhala i in. (2011) & Zaufanie instytucjonalne & 60 \\
\hline H. Akrout i in. (2016) & Zaufanie afektywne w relacjach B2B & 10 \\
\hline
\end{tabular}

Źródło: [Laeequddin i in. 2010, Akrout i in. 2016, Vanhala, Puumalainen i Blomqvist 2011].

Warto także pamiętać, że nie jest zalecane badanie tak skomplikowanych konstruktów jak zaufanie za pomocą skal ograniczonych do jednego lub dwóch twierdzeń. Podejście takie powoduje problemy z oszacowaniem rzetelności pomiaru, co decyduje o ograniczeniach w jego stosowaniu [Blunsdon i Reed 2003, Sankowska 2011].

W celu uzyskania rzetelnych narzędzi pomiarowych warto przy tworzeniu skal uwzględnić następujący porządek działań [Vanhala, Puumalainen i Blomqvist 2011]:

- dyskusję fokusową - dla lepszego zrozumienia, w jaki sposób pracownicy postrzegają dany konstrukt. Warto takie postępowanie powtórzyć w kilku jednorodnych pod względem zawodowym grupach, np. menedżerów, specjalistów HR, osób zajmujących się obsługą klienta i innych. Badania oparte na wywiadzie zogniskowanym pomagają także zidentyfikować elementy danego konstruktu. Warto przy tym posiłkować się oprogramowaniem do analizy danych jakościowych;

- panel ekspertów, który tworzy twierdzenia lub też przyporządkowuje twierdzenia do danych kategorii. Jest to szczególnie istotne, jeżeli brak pełnego przekonania co do tego, dla jakiej kategorii dane twierdzenia są diagnostyczne; 
- zebranie puli twierdzeń - staranna analiza skal dotychczas stosowanych w badaniach i selekcja tych twierdzeń, które można wykorzystać do celów badań, oraz przygotowanie listy twierdzeń stworzonych przez badaczy;

- wstępne testowanie twierdzeń przez badania pierwotne i wybór z puli pytań twierdzeń, które będą wykorzystywane w badaniach właściwych;

- badania pilotażowe do weryfikacji struktury poszczególnych czynników i rzetelności skal;

- badania właściwe.

Doświadczeni badacze zalecają również unikanie negatywnych twierdzeń w konstrukcji skal, ponieważ mogą utrudniać analizę wyników, przyczyniają się do błędów respondentów, którzy przez nieuwagę i przyzwyczajenie do pozytywnych twierdzeń mogą zaznaczyć niewłaściwą odpowiedź [Dietz i Hartog 2006]. Poza tym powstaje wątpliwość, czy negatywne twierdzenia mierzą niski poziom zaufania, czy nieufność, która według niektórych autorów jest zupełnie innym konstruktem [Lewicki i Bunker 1996].

Inne podejście wykorzystuje się do badań zachowań, które odzwierciedlają różny poziom zaufania. W tym podejściu najczęściej wykorzystywane są eksperymentalne metody, w których uczestnicy angażowani są w gry oparte na dylemacie więźnia (mixed-motive game) ujawniające skłonność do kooperacyjnych lub rywalizacyjnych zachowań. Konstrukcja takich gier umożliwia zwykle uzyskanie pozornych, krótkofalowych korzyści przy przyjęciu strategii rywalizacyjnej, ale tylko strategia oparta na współpracy umożliwia uzyskanie długofalowych korzyści ekonomicznych. Tego typu pomiary nad zaufaniem zapoczątkował M. Deutsh [1958], który w swoich badaniach stosował zachęty finansowe. Jeśli uczestnicy badania wykazywali się kooperacją, otrzymywali środki finansowe, jeśli rywalizacją - tracili je [Tschannen-Moran i Hoy 2000]. Podejście to jest jednak dość często krytykowane ze względu na trafność zewnętrzną związaną ze sztucznymi warunkami eksperymentu oraz trafność wewnętrzną wynikającą z faktu, że współpraca nie zawsze jest efektem zaufania [Sankowska 2011]. Mimo zdecydowanie większej popularności pierwszego z podejść badawczych coraz częściej wraca się do metod eksperymentalnych, oceniając przydatność obu podejść [Avner i Halldorsson 2006].

\section{Wnioski}

Przeprowadzony przez autorów przegląd literatury przedmiotu pozwala wskazać trudności, z którymi muszą się zmierzyć badacze zajmujący się zjawiskiem zaufania. Wśród nich warto zwrócić uwagę na: 
- trudności w definiowaniu zaufania ze względu na wielość kontekstów i poziomów, na których jest badane,

- naturę zaufania, które jest konstruktem poznawczym i subiektywnym, co utrudnia zarówno ilościowe, jak i jakościowe porównania wyników,

- korelacje pomiędzy różnymi rodzajami zaufania utrudniające precyzyjne określenie obszaru badań i operacjonalizację zmiennych.

W związku z tym wydaje się, że w projektach badawczych dotyczących zaufania powinno się rezygnować z fragmentaryczności na rzecz maksymalnie kompleksowego ujęcia, a także opierać się na zróżnicowanych metodach badawczych. Przeprowadzone analizy wskazują na dość jednorodne podejście metodyczne w badaniach nad zaufaniem. Warto byłoby zastosować w większym stopniu studia przypadków, jak również mniej statyczne podejście badawcze dostosowane do dynamicznego, zmieniającego się w czasie konstruktu.

Złożoność relacji wewnątrzorganizacyjnych i międzyorganizacyjnych (sieciowość, wirtualizacja, orientacja relacyjna) sprawia, że zaufanie mimo trudności $\mathrm{w}$ jego operacjonalizacji jest zagadnieniem nadal poruszanym $\mathrm{w}$ aktualnych badaniach.

Warto także wskazać następujące kierunki badań będące odpowiedzią na potrzeby współczesnych organizacji:

- zaufanie jako czynnik pośredniczący pomiędzy dwoma pozornie sprzecznymi oczekiwaniami wobec organizacji: ciągłą otwartością na zmiany a przewidywalnością, pewnością i stałością,

- wpływ standardów pracy zespołowej i poziomu zaufania na efektywność zespołów,

- zaufanie w relacjach on line dotyczące źródeł informacji, relacji z klientami, dostawcami itp.,

- zaufanie w zespołach projektowych, szczególnie w relacjach przełożonypodwładny,

- rola zaufania w budowaniu społeczności (pracowniczej, wobec marki, wokół produktu),

- wpływ zaufania wewnątrzorganizacyjnego na charakterystykę relacji nawiązywanych przez organizacje z interesariuszami zewnętrznymi.

\section{Literatura}

Akrout H., Fall M., Akrout W., Chandon J.L. [2016], Affective Trust in Buyer-Seller Relationships: A Two-dimensional Scale, ,Journal of Business and Industrial Marketing”, vol. 31, nr 2, http://dx.doi.org/10.1108/JBIM-11-2014-0223.

Altuntaş S., Baykal U. [2010], Relationship between Nurses' Organizational Trust Levels and Their Organizational Citizenship Behaviors, ,Journal of Nursing Scholarship”, vol. 42, https://doi.org/10.1111/j.1547-5069.2010.01347.x. 
Atkinson S., Butcher D. [2003], Trust in Managerial Relationships, „Journal of Managerial Psychology", vol. 18, nr 4, http://dx.doi.org/10.1108/02683940310473064.

Avner B.N., Halldorsson F. [2006], Measuring Trust: Which Measure Can Be Trusted?, http://www.legacy-irc.csom.umn.edu/RePEc/hrr/papers/0207.pdf (data dostępu: 20.09.2016).

Baccarani C. [1995], Riflessioni sulla fiducia in M.Ugolini. La natura dei rapporti tra imprese nel settore delle scarpe per donna, Cedam, Padova.

Beugelsdijk S., Groot H.L. de, Schaik A.B. van [2004], Trust and Economic Growth: A Robustness Analysis, „Oxford Economic Papers”, vol. 56(1), https://doi.org/10.1093/ oep/56.1.118.

Bigley G.A., Pearce I.L. [1998], Straining for Shared Meaning in Organization Science: Problems of Trust and Distrust, „Academy of Management Review”, vol. 23(3), https:// doi.org/10.2307/259286.

Blomqvist K. [2002], Partnering in the Dynamic Environment: The Role of Trust in Asymmetric Partnership Formation, Doctor of Science Thesis, Lappeenranta University of Technology, Lappeenranta.

Blunsdon B., Reed K. [2003], The Effect of Technical and Social Conditions on Workplace Trust, „International Journal of Human Resource Management”, vol. 14(1), https://doi.org/10.1080/09585190210158493.

Colquitt J.A., Scott B.A., LePine J.A. [2007], Trust, Trustworthiness, and Trust Propensity: A Meta-Analytic Test of Their Unique Relationships with Risk Taking and Job Performance, ,Journal of Applied Psychology”, vol. 92, nr 4, https://doi.org/ 10.1037/0021-9010.92.4.909.

Connell R. Mannion N.A.D. [2006], Conceptualisations of Trust in the Organisational Literature, ,Journal of Health Organization and Management”, vol. 20, nr 5, https://doi. org/10.1108/14777260610701795.

Cwalina W., Falkowski A. [2005]. Marketing polityczny-perspektywa psychologiczna, Gdańskie Wydawnictwo Psychologiczne, Gdańsk.

DeVellis R.F. [1991], Scale Development: Theory and Applications, Applied Social Research Methods Series, vol. 26, Sage, Newbury Park, CA.

Dietz G., Hartog D.N. den [2006], Measuring Trust inside Organisations, „Personnel Review", vol. 35, nr 5, https://doi.org/10.1108/00483480610682299.

Deutsh M. [1958], Trust and Suspicion, „Journal of Conflict Resolution”, vol. 2, nr 4, https://doi.org/10.1177/002200275800200401.

Ekici A. [2013], Temporal Dynamics of Trust in Ongoing Inter-organizational Relationships, „Industrial Marketing Management”, vol. 42, nr 6, https://doi.org/10.1016/j. indmarman.2013.03.008.

Ertürk A. [2010], Exploring Predictors of Organizational Identification: Moderating Role of Trust on the Associations between Empowerment, Organizational Support and Identification, „European Journal of Work and Organizational Psychology”, vol. 19, nr 4, https://doi.org/10.1080/13594320902834149.

Fischer C. [2013], Trust and Communication in European Agri-food Chains, „Supply Chain Management: An International Journal", vol. 18, nr 2, https://oi.org/10.1108/ 13598541311318836.

Gerrig R.J., Zimbardo P. [2006], Psychologia i życie, wyd. 3, PWN, Warszawa.

Gibson C.B., Manuel J.A. [2003], Building Trust: Effective Multicultural Communication Processes in Virtual Teams [w:] Virtual Teams That Work: Creating Conditions for Virtual Team Effectiveness, eds C.B. Gibson, S.G. Cohen, Jossey-Bass, San Francisco. 
Glińska-Neweś A. [2013], Employee Interpersonal Relationship [w:] Positive Management. Managing the Key Areas of Positive Organisational Potential for Company Success, ed. M.J. Stankiewicz, Dom Organizatora TNOiK, Toruń.

Glińska-Neweś A., Haffer R. [2013], Znaczenie interpersonalnych relacji pracowników w organizacyjnym uczeniu się, Dom Organizatora TNOiK, Toruń.

Gojny-Zbierowska [2015], Postrzegane wsparcie organizacyjne. Perspektywa wysoce efektywnych systemów pracy, Uniwersytet Ekonomiczny w Katowicach, Katowice (praca magisterska, maszynopis).

Good D. [1988], Individuals, Interpersonal Relations and Trust [w:] Trust Making and Breaking Relationships, ed. D. Gabmetta, Basil Blackwell, Oxford.

Gori-Maia A. [2013], Relative Income, Inequality and Subjective Wellbeing: Evidence for Brazil, ,Social Indicators Research”, vol. 113, nr 3, https://doi.org/10.1007/s11205012-0135-4.

Hosmer L.T. [1995], Trust: The Connecting Link between Organizational Theory and Philosophical Ethics, „Academy of Management Review”, vol. 20, nr 2, https://doi. org/10.2307/258851.

Inglehart R. [1999], Trust, Well-Being and Democracy [w:] Democracy and Trust, ed. M. Warren, Cambridge University Press, Cambridge.

Koopetycja w rozwoju przedsiębiorstw high-tech. Determinanty i dynamika [2014], red. A. Zakrzewska-Bielawska, Placet, Warszawa.

Korsgaard M.A., Brower H.H., Lester S.W. [2015], It Isn't Always Mutual: A Critical Review of Dyadic Trust, ,Journal of Management”, vol. 41, nr 1, https://doi. org/10.1177/0149206314547521.

Krot K. [2013], Holistyczne podejście do zaufania w zarzadzaniu przedsiębiorstwem [w:] Nauki o zarzadzaniu dla przedsiębiorstw i biznesu, red. A. Czech, A. Szplit, Wydawnictwo Uniwersytetu Ekonomicznego w Katowicach, Katowice.

Laeequddin M., Sahay B.S., Sahay V., Abdul Waheed K. [2010], Measuring Trust in Supply Chain Partners' Relationships, „Measuring Business Excellence”, vol. 14, nr 3, https://doi.org/10.1108/13683041011074218.

Larzelere R.E., Huston T.L. [1980], The Dyadic Trust Scale: Toward Understanding Interpersonal Trust in Close Relationships, „Journal of Marriage and the Family”, vol. 42, nr 3, August, https://doi.org/10.2307/351903.

Lencioni P.M. [2012], The Advantage. Why Organizational Health Trumps Everything Else in Business, Jossey Bass, San Francisco, CA.

Lewicki R.J., Bunker B.B. [1996], Developing and Maintaining Trust in Work Relationships [w:] Trust in Organizations. Frontiers of Theory and Re-search, eds R.M. Kramer, T.R. Tyler, Sage, London.

Lippert S.K., Swiercz P.M. [2005], Human Resource Information Systems (HRIS) and Technology Trust, ,Journal of Information Science”, vol. 31, nr 5, https:/doi. org/10.1177/0165551505055399.

Martin K.D., Cullen J.B. [2006], Continuities and Extensions of Ethical Climate Theory: A Meta-Analytic Review, ,Journal of Business Ethics”, vol. 69, nr 2, https://doi. org/10.1007/s10551-006-9084-7.

Meyer R.C., Davis J.H., Schoorman D. [1995], An Integrative Model of Organizational Trust, „Academy of Management Review”, vol. 20, nr 3, https://doi. org/10.2307/258792. 
McCole P. [2002], The Role of Trust for Electronic Commerce in Services, „International Journal of Contemporary Hospitality Management”, vol. 14, nr 2, https://doi. org/10.1108/09596110210419264.

McEvily B., Perrone V., Zaheer A. [2003], Trust as an Organizing Principle, „Organization Science", vol. 14, nr 1, https://doi.org/10.1287/orsc.14.1.91.12814.

McKnight D.H., Chervany N.L. [2001], Trust and Distrust Definitions: One Bite at a Time [w:] Trust in Cyber-societies, Springer Verlag, Berlin-Heidelberg.

Migdał K. [2003], Psychologia w praktyce społecznej, wyd. 2, Wydawnictwo Wyższej Szkoły Ekonomicznej, Warszawa.

Miszczak M. [2010], Emocje w komunikacji interpersonalnej z perspektywy zarzadzania [w:] Psychologiczne aspekty zarzadzania organizacja, cz. 3, http://www.wcy.wat.edu. pl/ioz/stories/zeszyty/new_nsz7_03.pdf (data dostępu: 20.09.2016).

Morita P.P., Burns C.M. [2014], Understanding 'Interpersonal Trust' from a Human Factors Perspective: Insights from Situation Awareness and the Lens Model, „Theoretical Issues in Ergonomics Science”, vol. 15, nr 1, https://doi.org/10.1080/14639 22x.2012.691184.

Mouzas S., Henneberg S., Naude P. [2007], Trust and Reliance in Business Relationships, „European Journal of Marketing”, vol. 41, nr 9/10, https://doi.org/10.1108/ 03090560710773327.

Nienaber A.M., Romeike P.D, Searle R., Schewe G. [2015], A Qualitative Meta-analysis of Trust in Supervisor-subordinate Relationships, ,Journal of Managerial Psychology", vol. 30, nr 5, https://doi.org/10.1108/jmp-06-2013-0187.

Paine K.D. [2003], Guidelines for Measuring Trust in Organizations, The Institute for Public Relations, http://www.instituteforpr.org/wpcontent/uploads/2003_MeasuringTrust.pdf (data dostępu: 10.09.2016).

Piórkowska K. [2014], Treści kognitywne i metodologiczne psychologii społecznej i poznawczej w kontekście nauk o zarzadzaniu, Prace Naukowe Uniwersytetu Ekonomicznego we Wrocławiu, nr 340, Wrocław, https://doi.org/10.15611/pn.2014.340.10.

Pluwak A. [2009], Geneza i ewolucja pojęcia framing w naukach społecznych, http:// www.globalmediajournal.collegium.edu.pl/artykuly/wiosna-2009/pluwak-geneza-i-ewolucja-pojecia-framing.pdf (data dostępu: 14.01.2016).

Rosenfeld R., Messner S.F., Baumer E.P. [2001], Social Capital and Homicide, „Social Forces", vol. 80, nr 1.

Sako M. [2006], Outsourcing and Offshoring: Implications for Productivity of Business Services, „Oxford Review of Economic Policy”, vol. 22(4).

Sankowska A. [2011], Wpływ zaufania na zarzadzanie przedsiębiorstwem. Perspektywa wewnatrzorganizacyjna, Difin, Warszawa.

Schoorman F.D., Mayer R.C., Davis J.H. [2007], An Integrative Model of Organizational Trust: Past, Present and Future, „Academy of Management Review”, vol. 32, nr 2, https://doi.org/10.5465/amr.2007.24348410.

Seppanen R., Blomqvist K., Sundqvist S. [2007], Measuring Inter-organizational Trust - a Critical Review of the Empirical Research in 1990-2003, ,Industrial Marketing Management", vol. 36, nr 2, https://doi.org/10.1016/j.indmarman.2005.09.003.

Sokołowska A. [2015], Kształtowanie zaufania pracowników w małym przedsiębiorstwie - główne założenia, dylematy i paradoksy, „Marketing i Rynek”, nr 5.

Stewart K.J. [2003], Trust Transfer on the World Wide Web, „Organization Science”, vol. 14, nr 1, https://doi.org/10.1287/orsc.14.1.5.12810. 
Svensson G. [2006], Multiple Informants and Asymmetric Interactions of Mutual Trust in Dyadic Business Relationships, „European Business Review”, vol. 18, nr 2, https:// doi.org/10.1108/09555340610651848.

Sztompka P. [2007], Zaufanie. Fundament spoteczeństwa, Znak, Kraków.

Tschannen-Moran M., Hoy W.K. [2000], A Multidisciplinary Analysis of the Nature, Meaning, and Measurement of Trust, ,Review of Educational Research”, vol. 70, $\mathrm{nr} 4$, https://doi.org/10.2307/1170781.

Van Dyne L., Vandewalle D., Kostova T., Latham M., Cummings L. [2000], Collectivism, Propensity to Trust and Self-esteem as Predictors of Organizational Citizenship in a Non-work Setting, ,Journal of Organizational Behavior”, vol. 21, nr 1, https://doi. org/10.1002/(sici)1099-1379(200002)21:1\%3C3::aid-job47\%3E3.0.co;2-6.

Vanhala M., Puumalainen K., Blomqvist K. [2011], Impersonal Trust: The Development of the Construct and the Scale, „Personnel Review”, vol. 40, nr 4, https://doi. org/10.1108/00483481111133354.

Weck M., Ivanova M. [2013], The Importance of Cultural Adaptation for the Trust Development within Business Relationships, ,Journal of Business and Industrial Marketing", vol. 28, nr 3, https://doi.org/10.1108/08858621311302868.

Wierzbiński J. [2009], Badanie zaufania do organizacji: problemy metodologiczne, Wydawnictwo Naukowe Wydziału Zarządzania Uniwersytetu Warszawskiego, Warszawa.

Williamson O. [1985], The Economic Institutions of Capitalism, Free Press, New York.

Wrightsman L.S. [1996], Personality and Attitudinal Correlates of Trusting and Trustworthy Behaviors in a Two-Person Game, ,Journal of Personality and Social Psychology”, vol. 4(3), https://doi.org/10.1037/h0023655.

Zhang J., Cohen R. [2008], Evaluating the Trustworthiness of Advice about Seller Agents in e-marketplaces: A Personalized Approach, „Electronic Commerce Research and Applications", vol. 7, nr 3, https://doi.org/10.1016/j.elerap.2008.03.001.

Zieliński T. [2012], Zaufanie jako regulator decyzji ekonomicznych (analiza literatury), „Management and Business Administration. Central Europe”, nr 4(117), https://doi. org/10.7206/mba.ce.2084-3356.24.

\section{Methodological Aspects of Researching Trust in Management Sciences (Abstract)}

This article presents an overview of the problems associated with the study of trust in management science. Trust can be considered in various contexts and ranges. Its varied sources and dimensions, cultural roots and numerous other features have made it difficult to analyse and reconcile in the research done by various authors. Another reason studying trust is difficult is that it is a cognitive construct, and it is often researched based on the subjective perception of respondents. The article attempts the most comprehensive approach to issues of trust with regard to the problems associated with measuring it.

Keywords: interorganisational trust, intraorganisational trust, trust propensity, methodology of research. 